\title{
Health Risks Associated with Occupational Exposure to Biological Air Pollutants Occurring during the Processing of Biomass for Energy Purposes: A Case Study
}

\author{
Ewa Bragoszewska * (D) and Maja Pawlak
}

Citation: Bragoszewska, E.; Pawlak, M. Health Risks Associated with Occupational Exposure to Biological Air Pollutants Occurring during the Processing of Biomass for Energy Purposes: A Case Study. Energies 2021, 14, 2086. https://doi.org/ 10.3390/en14082086

Academic Editor: Gheorghe Badea

Received: 1 March 2021

Accepted: 7 April 2021

Published: 9 April 2021

Publisher's Note: MDPI stays neutral with regard to jurisdictional claims in published maps and institutional affiliations.

Copyright: (c) 2021 by the authors. Licensee MDPI, Basel, Switzerland. This article is an open access article distributed under the terms and conditions of the Creative Commons Attribution (CC BY) license (https:// creativecommons.org/licenses/by/ $4.0 /)$.
Department of Technologies and Installations for Waste Management, Faculty of Energy and Environmental Engineering, Silesian University of Technology, 18 Konarskiego St., 44-100 Gliwice, Poland; maja_pawlak@interia.pl

* Correspondence: ewa.bragoszewska@polsl.pl

\begin{abstract}
The main goal of this study was to assess the levels of concentration of biological air pollutants in biomass processing power plants, based on the measurements taken in a plant located in Southern Poland. This work shows problems related to the co-combustion of biomass and indicates the health risks to which employees of positions closely related to the processing and combustion of biomass are exposed. Bacterial and fungal aerosol samples were collected using a six-stage Andersen cascade impactor with aerodynamic cut-off diameters of 7.0, 4.7, 3.3, 2.1, 1.1 and $0.65 \mu \mathrm{m}$ (Tisch Environmental, USA). The highest average concentration level of micro-organisms was recorded in the air in the biomass analysis laboratory, where there was no constant airflow. It was found that the concentration levels of biological agents were below the Polish proposals for threshold limit values in the work environment polluted with organic dust. However, it was observed that the share of the respirable fraction (RF) of bacterial aerosol (particles less than $3.3 \mu \mathrm{m}$ ) in workplaces was equal to or higher than $50 \%$ of the total concentration, which may cause increased potentially adverse health effects and problems with concentration among power plant employees. Therefore, to ensure adequate air quality in the tested object, it is necessary to properly ventilate. This preliminary research could be the important starting point for a complete and precise assessment of bioaerosol exposures in biomass processing power plants in order to protect workers' health.
\end{abstract}

Keywords: bioaerosol; biomass processing; power plant; bacterial aerosol; fungal aerosol; occupational hazard

\section{Introduction}

Renewable energy sources are an alternative to traditional energy carriers because they reduce the harmful impact of the energy sector on the natural environment by reducing harmful substances. One of the most popular renewable energy sources is biomass [1]. Almost 200 years ago, biomass was the main carrier of primary energy used by humans. Since the 1990s, interest in biomass and its use has been gradually increasing [2]. In the near future, the use of this energy source is expected to increase. Biomass brings local benefits, e.g., increasing the level of energy security, creating new workplaces and promoting regional development, and global environmental benefits, e.g., reduction of $\mathrm{CO}_{2}[3,4]$.

The main advantage of using alternative energy sources is that their resources complement each other in natural processes, and their acquisition is much more environmentally friendly. Biomass is increasingly being used for power generation; however, assessments of the potential occupational health problems related to the processing of biomass are very limited. Despite the many benefits of biomass, its processing carries a high health risk to central-heating plant workers from exposure to biological air pollutants, e.g., bacteria, microscopic fungi, and viruses [5]. 
Nowadays, it is necessary to assess the danger of workplace breathable air in order to protect the health of workers there and prevent the onset of chronic and dangerous diseases as much as possible [6]. The biggest threat to the health of people working in the processing of biomass is organic dust [7], which arises both in the process of use and processing. Previous Polish research stated that biomass is the primary source of bacteria at power plant workplaces. These results also showed that bacteria associated with biomass could be easily transferred to workers' hands and masks during routine activities [8].

In the European Union (EU) countries, coal will cease to be a source of energy after 2050 and will be replaced by renewable energy sources [9]. The popularity of biomass in the Polish energy sector is growing every year [10,11]. It is very important because Poland still has the worst value of ecological sustainability indicator for the amount of carbon dioxide equivalent (ton) per capita emitted in the atmosphere, due to the anthropic activities and is still far from that of the other European countries like Germany, France, Italy, and Spain [12]. Therefore, biomass should be a source of energy that is most often used by Polish power plants, and the combined heat and power plants' use of biomass reduces carbon dioxide emission into the atmosphere. Thus, it helps meet the EU requirements.

The use of biomass in Poland also brings many economic benefits, not only for local communities but also for the entire country [13,14]. It has an impact on reducing carbon dioxide emissions, contributes to an increase in the number of jobs, and allows for the management of agricultural wasteland. It also allows for the safe disposal of waste and contributes to regional development. The Polish energy industry uses forest biomass in the form of wood chips or pellets most often, which usually does not cause major combustion problems. The big problem is that forest biomass resources are limited, while the existing agro-mass resources in the form of straw, greenery, and biowaste are available in large amounts but are most often wasted by rotting in fields and emitting carbon dioxide [15].

The organic dust generated in the processing and use of biomass is the main health hazard for workers who come into contact with this fuel $[5,16]$. The dust contains both plant substances and micro-organisms that develop in it, which have a disastrous effect on the human body through toxic, irritating, and allergenic effects. The type of source materials, material processing, climatic conditions, and storage technology are the main environmental factors influencing the potential pathogenicity and the concentration of fungi and bacteria in the dust [17]. Combined heat and power plant workers represent a group particularly exposed to the risks associated with the presence of high concentrations of biological air pollutants [18].

The bacteria and fungi found in organic dust are generally non-infectious but can be harmful to the respiratory system. Bioaerosols can cause various types of diseases: mucous membrane irritation (MMI), chronic obstructive pulmonary disease, immunotoxic diseases such as organic dust toxic syndrome (ODTS), allergic diseases (allergic alveolitis, asthma, and allergic rhinitis), and irritation of the mucous membranes, conjunctiva, and skin [19]. The mucosa of the respiratory system most often becomes the gateway to infection by micro-organisms. Infectious agents for most of the diseases listed above are transmitted by air. The most common ailment caused by various types of air pollution is allergy (an excessive reaction of the body to the presence of allergens), in which large amounts of antibodies are produced [20].

Simple and effective methods to determine the biological aerosol concentration are lacking, and consequently, almost no bioaerosol exposure limits are available [21]. Most of the studies about microbiological air quality in workplaces have focused on the total concentration of bioaerosols. This information is indispensable for the assessment of population exposure, as well as for the identification of biological aerosols emission sources. However, it is especially important to garner information about particle size concentrations of bioaerosols, as this is critical to their fate in the air and their deposition in the human respiratory system [22]. Bioaerosols vary considerably in size, from approximately 0.02 to $100 \mu \mathrm{m}$. The particle size distribution (PSD) of bioaerosols depends upon the type of micro-organism species, age of the spore and nutrient medium, humidity, differences in 
aggregation rates of the spores, and the type of particles they are associated with, such as mist or dust [23]. The higher the respirable fraction (RF) of bioaerosols (particles less than $3.3 \mu \mathrm{m}$ ), the more damage they cause in the body by penetrating the deepest tissues of the body [24-26]. A serious occupational hazard to people exposed to organic dust is poisoning with toxins produced by micro-organisms. Mycotoxins, which are highly toxic, mutagenic, and carcinogenic, may be present in organic dust [27].

The aim of this study is to explore the assessment of problems related to the cocombustion of biomass in boilers and indicate the risks to which power plant employees of positions closely related to the processing and combustion of biomass are exposed. The study focuses on determining the level and size distribution of biological air pollutants generated during biomass processing for energy purposes, thus increasing awareness of their possible human health hazards. The results may have wider implications for knowledge of biological air pollutants related to the processing of biomass in the energy sector.

\section{Materials and Methods}

\subsection{Sampling Site}

The study was conducted in four different stations of a power plant in Southern Poland during January 2020. Table 1 shows the quality parameters of biomass currently co-fired with fine coal at the power plant. The measurements were made in the area of the power plant where group I (wood chips) of biomass is processed.

Table 1. Quality parameters of biomass currently burned at the power plant in Southern Poland.

\begin{tabular}{ccc}
\hline Group & Group I (Wood) & Group II (Agro-Mass) \\
\hline Biomass type & Wood chips & Sunflower husk pellets \\
Minimum calorific value [kJ/kg] & 7500 & 16,900 \\
Total moisture value [\%] & 51 & 9 \\
Ash value [\%] & 5 & 3 \\
Sulphur value [\%] & 0.01 & 0.1 \\
Chlorine value [\%] & 0.01 & 0.09 \\
Elemental carbon & 23 & 43 \\
\hline
\end{tabular}

\subsection{Sampling and Analysis}

The samples of biological aerosol concentrations were taken using a six-stage Andersen cascade impactor with cut-off diameters of 7.1, 4.7, 3.3, 2.1, 1.1, and $0.65 \mu \mathrm{m}$ (Figure 1). The impactor was designed to measure the concentration of specific size distributions of micro-organisms in the air of the tested environment. The structure of the impactor, the diameter of the openings of each segment, together with the flow used, enables the distribution of the aerosol fraction into groups with aerodynamic diameters corresponding to the penetration of various places in the human respiratory system.

The subsequent bioaerosol fractions on each segment were immediately transferred to Petri dishes filled with agar medium. The Petri dishes were then subjected to qualitative analysis. The air sampling device was set at a height of approximately 1.5 metres in order to simulate aspiration from the human inhalation zone. Four measurement points were selected for the research (Table 2). To determine the 'external background,' the bioaerosol collected in the outdoor air at a considerable distance from the workstations was tested.

Table 2. Sampling points in the power plant.

\begin{tabular}{cc}
\hline No. & Measuring Station \\
\hline 1 & Bio-raw materials unloading yard \\
2 & Biomass analysis laboratory \\
3 & Weight conveyor \\
4 & Outdoor air \\
\hline
\end{tabular}


a)

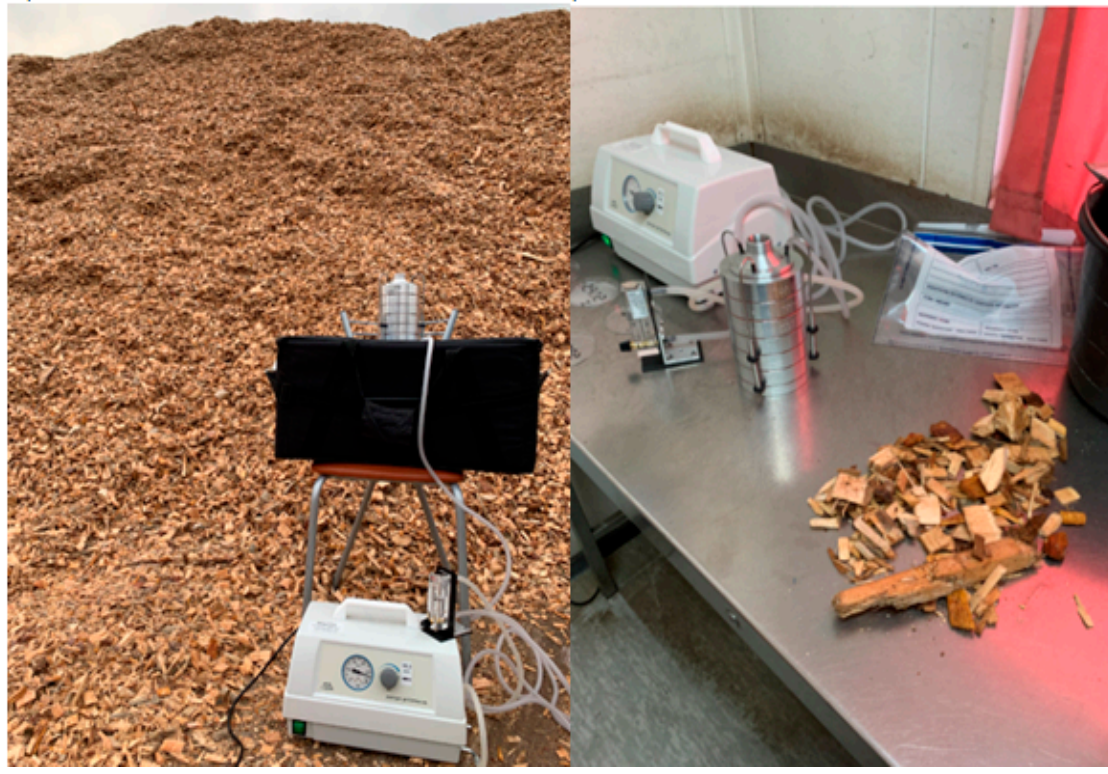

c)

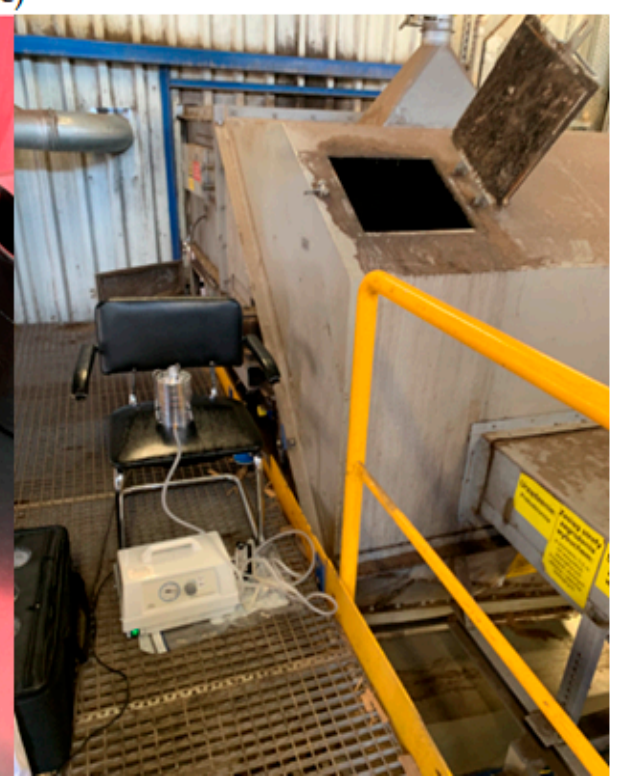

Figure 1. The six-stage Andersen cascade impactor used during measurements in (a) unloading yard, (b) biomass analysis laboratory, and (c) weight conveyor.

The airflow during the sampling was $28.3 \mathrm{dm}^{3} / \mathrm{min}$, controlled by a rotameter with a sampling time of $10 \mathrm{~min}$ [28]. The impactor was disinfected using $70 \%$ ethanol-immersed cotton balls between each sampling. After sampling, the Petri dishes were wrapped with a masking tape (as a control to minimize unexpected contamination), stored at $4{ }^{\circ} \mathrm{C}$ (using a portable plastic cooler box), and moved to a laboratory.

Malt extract agar (MEA 2\%) was applied to the fungi, with chloramphenicol added for the cultivation and maintenance of the pathogenic and non-pathogenic fungal species' growth, especially dermatophytes. By adding chloramphenicol, the selectivity of the medium was achieved. For bacteria, Trypticase soy LAB-AGAR was used with cycloheximide added to inhibit fungal growth. The samples of fungi were incubated for 5 to 6 days at $26^{\circ} \mathrm{C}$ and the samples of bacteria for $48 \mathrm{~h}$ at $36 \pm 1{ }^{\circ} \mathrm{C}$.

The total colony counts of biological aerosols were revised for multiple impactions by the positive hole method and expressed as colony-forming units (CFUs) per cubic metre of air [29]. Quality control was practised in accordance with standards PN-EN 12322 [30] and ISO 11133 [31].

\subsection{Statistical Analyses}

The concentration values reported in this study were presented as the mean values. Due to a nonparametric distribution of the collected data (analysed with the Shapiro-Wilk test), the results were analysed using the Mann-Whitney $U$ test to assess differences at the sampling sites. Statistically significant differences were determined when a probability $p$-value was lower than 0.05 .

\section{Results and Discussion}

\subsection{Total Concentration of Bioaerosol}

The values of the bacterial and fungal aerosol concentrations $\left[\mathrm{CFU} / \mathrm{m}^{3}\right]$ in the air at workplaces and in the outdoor air measured with the Andersen impactor are presented in Table 3 and Figure 2. 
Table 3. The average concentration and size distribution, $\mathrm{CFU} / \mathrm{m}^{3}$ of micro-organism colony-forming units per cubic metre.

\begin{tabular}{|c|c|c|c|c|c|}
\hline \multirow[b]{2}{*}{ Bacteria } & \multirow[b]{2}{*}{ Fraction $(\mu \mathrm{m})$} & \multicolumn{4}{|c|}{ Average Concentration, $\mathrm{CFU} / \mathrm{m}^{3}$} \\
\hline & & $\begin{array}{c}\text { Bio-Raw } \\
\text { Materials } \\
\text { Unloading Yard }\end{array}$ & $\begin{array}{l}\text { Biomass } \\
\text { Analysis } \\
\text { Laboratory }\end{array}$ & $\begin{array}{l}\text { Weight } \\
\text { Conveyor }\end{array}$ & Outdoor Air \\
\hline & $>7.1$ & 53 & 87 & 42 & 46 \\
\hline & $7.1-4.7$ & 67 & 72 & 53 & 68 \\
\hline & $4.7-3.3$ & 92 & 147 & 94 & 69 \\
\hline & $3.3-2.1$ & 120 & 173 & 87 & 72 \\
\hline & $2.1-1.1$ & 92 & 124 & 64 & 57 \\
\hline & $1.1-0.65$ & 44 & 71 & 39 & 28 \\
\hline & Total & 468 & 673 & 378 & 341 \\
\hline & RF & 256 & 367 & 190 & 158 \\
\hline & Share $(\%)$ of RF & 55 & 54 & 50 & 46 \\
\hline Fungi & Fraction $(\mu \mathrm{m})$ & $\begin{array}{c}\text { Bio-raw } \\
\text { materials } \\
\text { unloading yard }\end{array}$ & $\begin{array}{l}\text { Biomass } \\
\text { analysis } \\
\text { laboratory }\end{array}$ & $\begin{array}{l}\text { Weight } \\
\text { conveyor }\end{array}$ & Outdoor air \\
\hline & $>7.1$ & 35 & 55 & 55 & 35 \\
\hline & $7.1-4.7$ & 85 & 60 & 42 & 44 \\
\hline & $4.7-3.3$ & 94 & 111 & 71 & 41 \\
\hline & $3.3-2.1$ & 65 & 113 & 65 & 51 \\
\hline & $2.1-1.1$ & 27 & 62 & 58 & 53 \\
\hline & $1.1-0.65$ & 18 & 37 & 35 & 27 \\
\hline & Total & 323 & 438 & 327 & 251 \\
\hline & $\mathrm{RF}$ & 110 & 212 & 159 & 131 \\
\hline & Share (\%) of RF & 34 & 48 & 49 & 52 \\
\hline
\end{tabular}

RF-respirable fraction of bioaerosol $(0.65-3.3 \mu \mathrm{m})$.

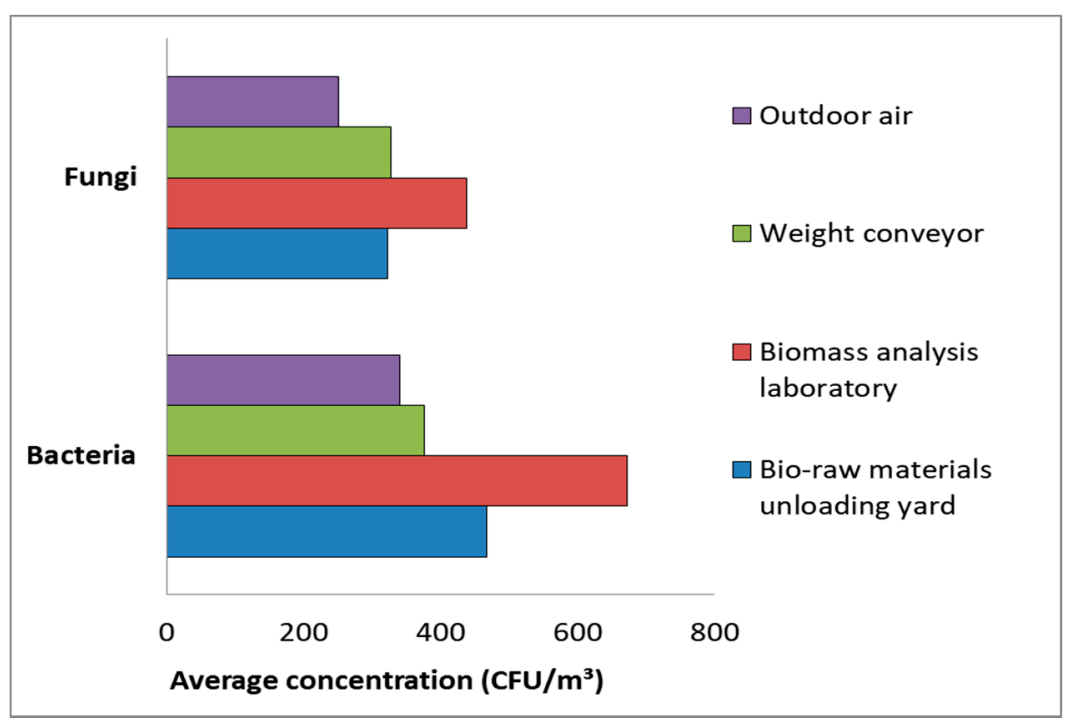

Figure 2. Indoor and outdoor average concentration levels $\left(\mathrm{CFU} / \mathrm{m}^{3}\right)$ in different sampling points.

The Mann-Whitney U test confirmed significant differences in the concentration levels of bacterial and fungal micro-organisms between the individual measuring stations and the outdoor air with $\mathrm{p}$-values $<0.05$. The highest average concentration both of bacterial and fungal aerosol was recorded in the biomass analysis laboratory $\left(673 \mathrm{CFU} / \mathrm{m}^{3}\right.$ and $438 \mathrm{CFU} / \mathrm{m}^{3}$, respectively). The lowest concentrations of biological aerosol were recorded in the outdoor air, where the concentration of airborne bacteria was $341 \mathrm{CFU} / \mathrm{m}^{3}$ and fungi $251 \mathrm{CFU} / \mathrm{m}^{3}$. 
In Poland and many other countries, the legislation governing microbiological standards for air pollution has not been developed and implemented. The main reason for this is a huge variety of air microflora and a large variety of methods. Therefore, there are no accepted criteria for assessing exposure to biological agents. The proposed standards for rooms polluted with organic dust are $1.0 \times 10^{5} \mathrm{CFU} / \mathrm{m}^{3}$ for mesophilic bacteria and $5.0 \times 10^{4} \mathrm{CFU} / \mathrm{m}^{3}$ for fungi [32]. The concentration levels of culturable bacteria and fungi obtained in this study were below the proposed standards.

\subsection{Indoor-to-Outdoor-Ratio (I/O)}

Throughout the biological aerosol sampling in any indoor environment, outdoor biological aerosol sampling should be performed for comparison of indoor and/or outdoor source strengths. Comparing the bioaerosol levels present in indoor environments with those in outdoor areas can be a useful tool to indicate whether the concentration of indoor bioaerosols is affected by both indoor and outdoor environments [33]. The indoor-tooutdoor ratio $(\mathrm{I} / \mathrm{O})$ shows where the source of bioaerosol might be found.

In this study, since the I/O ratio was $>1$, it can be concluded that the major source of bioaerosols is biomass analysis and processing for energy purposes (Figure 3). The highest average I/O ratio calculated for bacteria and fungi concentrations observed in the biomass analysislaboratory was 1.97 and 1.75 , respectively, with the peak of micro-organisms' sizes from $2.1 \mu \mathrm{m}$ to $3.3 \mu \mathrm{m}$ (Figures 4 and 5). In the weight conveyor station and during bio-raw materials unloading yard, the average $\mathrm{I} / \mathrm{O}$ value calculated for bacteria concentrations was 1.3 and 1.4, and for fungi was 1.1 and 1.3, respectively (Figure 3).

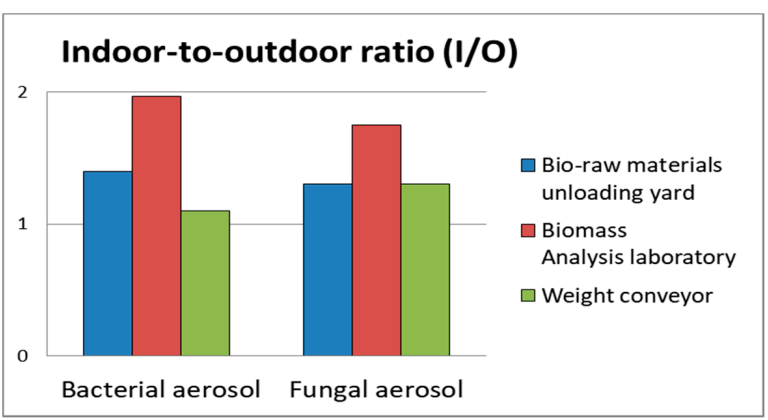

Figure 3. The total average concentration $\left(\mathrm{CFU} / \mathrm{m}^{3}\right)$ of culturable bacteria and fungi in the studied outdoor and indoor air and the values of the indoor-to-outdoor ratio(I/O).

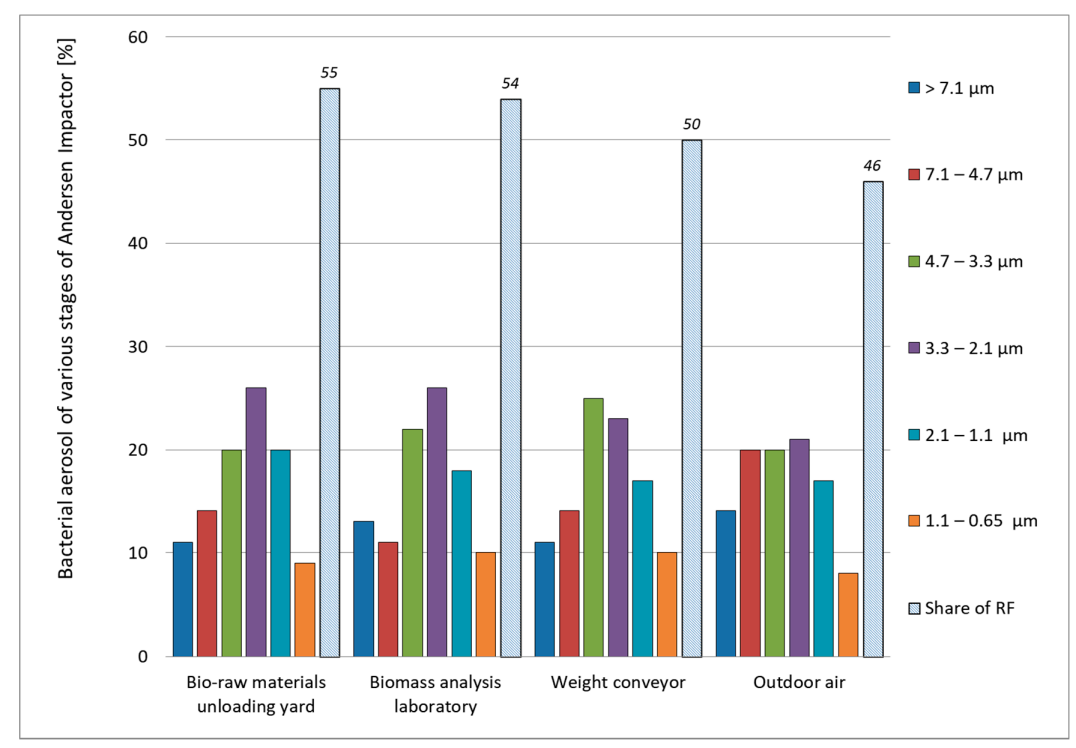

Figure 4. Particle size distribution (PSD) of bacterial aerosol in the analysed power plant. 


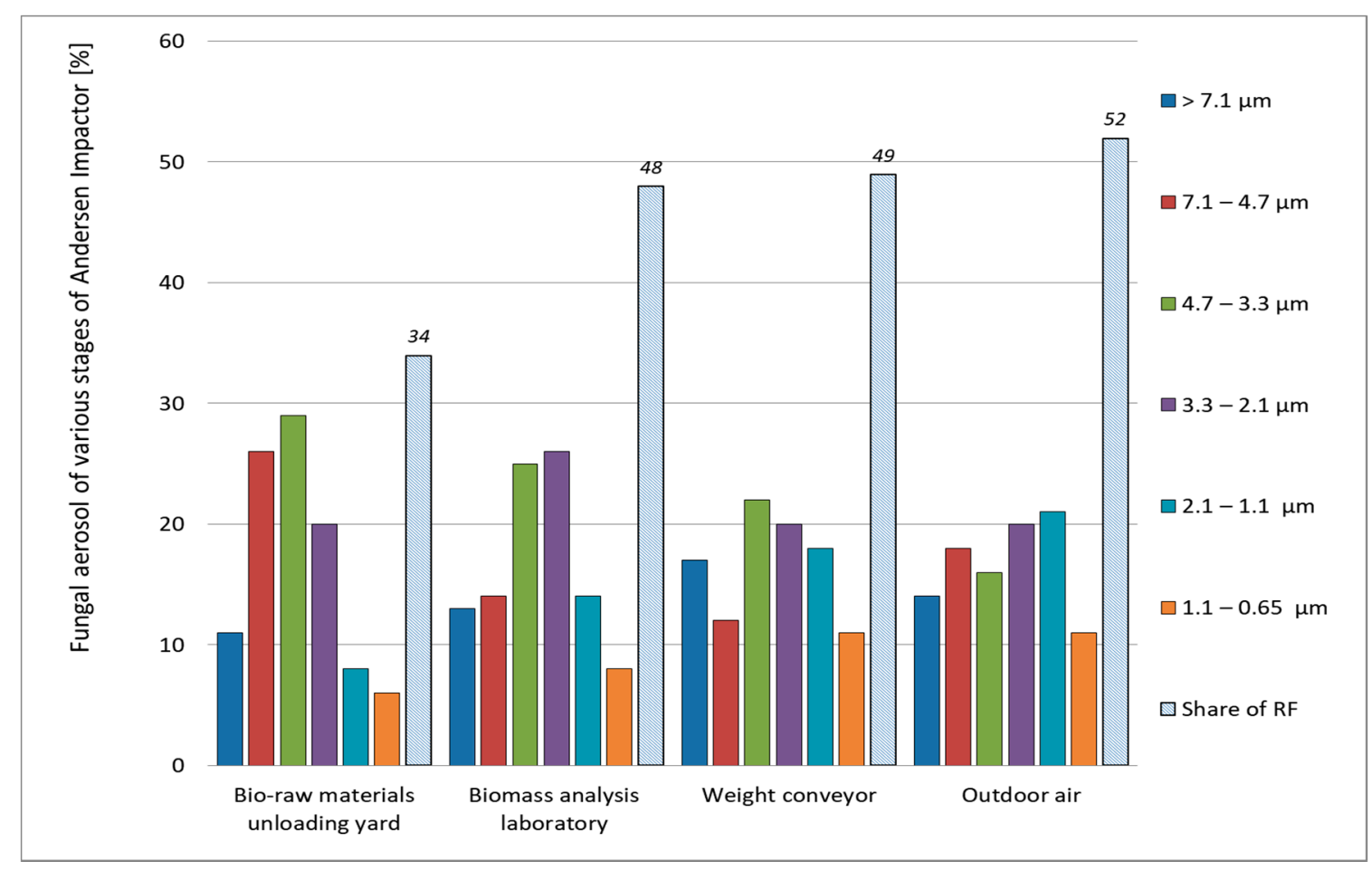

Figure 5. Particle size distribution (PSD) of fungal aerosol in the analysed power plant.

\subsection{Particle Size Distribution (PSD) of Bioaerosols}

The influence of bioaerosols on human health is not only related to their concentrations. The aerodynamic diameters of bioaerosols determine their potential to be deposited either in the tracheal, bronchial, or alveolar regions of the lungs, so their size distribution is also important $[20,34]$. The use of the six-stage Andersen impactor allowed us to obtain data on the grain distribution of micro-organisms and to determine how deeply they penetrate the respiratory system of power plant workers. The particle size distribution (PSD) of airborne bacteria and fungi collected from the air of the analysed power plant is shown in Figures 4 and 5, respectively.

The share of respirable fraction (RF) of bacterial aerosol observed in workplaces is equal to or higher than $50 \%$ of the total concentration (Figure 4). In the case of fungal aerosol, the highest share of RF indoors was found in the weight conveyor $(49 \%)$ and biomass analysis laboratory ( $48 \%$ ) (Figure 5). Due to their small size, the RF particles are expected to stay airborne for a longer time than larger particles, and the period of exposure may be extended [35]. Such results could indicate the existence of a serious potential exposure of workers to particles of respirable sizes, which may reach the trachea, bronchi, and alveoli and contribute to adverse symptoms in the respiratory system [36,37].

Moreover, we observed a high contribution of fungal RF in the outdoor air (52\%) from the sampling point near the power plant. However, the level of RF of micro-organisms in the outdoor air may fluctuate strongly, depending on the instantaneous values of meteorological parameters and the local structure of bioaerosol [38]. Thus, it is necessary to further conduct microbiological outdoor air quality monitoring in all four seasons of the year.

The research analysis showed that, in the outdoor air, the shape of the PSD for bacteria and fungi is rather "flattened." Moreover, in the case of bacteria, an increase was observed in the concentration of coarse bacterial particles in the atmospheric air. This may be due to the adhesion of small, respirable bacteria (less than $3.3 \mu \mathrm{m}$ ) to the coarse dust particles suspended in the air. 


\section{Conclusions}

The present work highlights the problem of exposed employees of power plants and combined heat and power plants to biological air pollutants in workplaces related to biomass processing. The results of biological factors' measurements show that the highest concentrations of bioaerosol occur indoors, in closed stations, where there is no constant airflow. The concentration levels of airborne micro-organisms were below Polish proposals for threshold limit values in the work environment polluted with organic dust.

The share of the respirable fraction (RF) of bacterial aerosol (particles less than $3.3 \mu \mathrm{m}$ ) in workplaces was equal to or higher than $50 \%$ of the total concentration. Additionally, this result increases the health risk to the exposed staff. However, in future work, it is necessary to conduct the identification of bacteria and fungi species, which may lead to a complete and precise assessment of bioaerosol exposures occurring during the processing of biomass for energy purposes. The high contribution of fungal RF in the outdoor air (52\%) from the sampling point near the power plant was observed. Thus, it is necessary to conduct further microbiological outdoor air quality monitoring in all four seasons of the year.

The encapsulation of biomass processes should be pursued, and the work environment should be regularly monitored for the presence of hazards caused by microbiological agents in order to reduce the exposure of workers employed in power plants co-firing biomass. This study indicates that the use of personal protective equipment is necessary. The research also showed that natural ventilation does not provide high-quality microbiological air in a closed room, such as a laboratory. In such a setting, an efficient and mechanical ventilation system should be introduced, which would ensure less exposure to contact with fungi and bacteria.

The research indicated that exposure to the bioaerosols present in the tested power plant does not pose a direct threat to the health of employees. However, long-term inhalation of micro-organisms can cause negative health effects, especially for people sensitive to microbial air pollution. This may be manifested by greater susceptibility to diseases of the upper respiratory tract, headache, watery eyes, itchy skin, or coughing.

Author Contributions: Conceptualization, E.B.; Data curation, E.B. and M.P.; Methodology, E.B.; Supervision, E.B.; Visualization, M.P.; Writing-original draft, E.B. and M.P.; Writing-review \& editing, E.B. All authors have read and agreed to the published version of the manuscript.

Funding: Publication supported as a part of the rector's habilitation grant. The Silesian University of Technology, grant number: 08/030/RGH19/0069.

Institutional Review Board Statement: Not applicable.

Informed Consent Statement: Not applicable.

Conflicts of Interest: The authors declare no conflict of interest

\section{References}

1. Drożyner, P.; Rejmer, W.; Starowicz, P.; Klasa, A.; Skibniewska, K. Biomass as a Renewable Source of Energy. Tech. Sci. Univ. Warm. Mazury Olszt. 2013, 16, 211-220.

2. Janowicz, L. Biomass in Poland. Energy Ecol. 2006, 8, 601-604. (In Polish)

3. Morimoto, S.; Miyamoto, K. A Current Review of Social Impact Assessment on Sustainable Biomass/Biofuel Development. J. Jpn. Inst. Energy 2009, 88, 133-139. [CrossRef]

4. Paletto, A.; Bernardi, S.; Pieratti, E.; Teston, F.; Romagnoli, M. Assessment of environmental impact of biomass power plants to increase the social acceptance of renewable energy technologies. Heliyon 2019, 5, e02070. [CrossRef]

5. Rohr, A.C.; Campleman, S.L.; Long, C.M.; Peterson, M.K.; Weatherstone, S.; Quick, W.; Lewis, A. Potential Occupational Exposures and Health Risks Associated with Biomass-Based Power Generation. Int. J. Environ. Res. Public Health 2015, 12, 8542-8605. [CrossRef] [PubMed]

6. Bruni, E.; Simonetti, G.; Bovone, B.; Casagrande, C.; Castellani, F.; Riccardi, C.; Pomata, D.; Di Filippo, P.; Federici, E.; Buiarelli, F.; et al. Evaluation of Bioaerosol Bacterial Components of a Wastewater Treatment Plant Through an Integrate Approach and In Vivo Assessment. Int. J. Environ. Res. Public Health 2019, 17, 273. [CrossRef] [PubMed]

7. Freiberg, A.; Scharfe, J.; Murta, V.C.; Seidler, A. The Use of Biomass for Electricity Generation: A Scoping Review of Health Effects on Humans in Residential and Occupational Settings. Int. J. Environ. Res. Public Health 2018, 15, 354. [CrossRef] 
8. Ławniczek-Wałczyk, A.; Gołofit-Szymczak, M.; Cyprowski, M.; Stobnicka, A.; Górny, R.L. Monitoring of bacterial pathogens at workplaces in power plant using biochemical and molecular methods. Int. Arch. Occup. Environ. Health 2017, 90, $285-295$. [CrossRef] [PubMed]

9. A Clean Planet for All. In A European Long-Term Strategic Vision for a Prosperous, Modern, Competitive and Climate Neutral Economy; European Commission: Brussels, Belgium, 2018.

10. Koryś, K.A.; Latawiec, A.E.; Grotkiewicz, K.; Kuboń, M. The Review of Biomass Potential for Agricultural Biogas Production in Poland. Sustainability 2019, 11, 6515. [CrossRef]

11. Baum, R.; Wajszczuk, K.; Pepliński, B.; Wawrzynowicz, J. Potential For Agricultural Biomass Production for Energy Purposes in Poland: A Review. Contemp. Econ. 2013, 7, 63-74. [CrossRef]

12. Torchio, M.; Lucia, U.; Grisolia, G. Economic and Human Features for Energy and Environmental Indicators: A Tool to Assess Countries' Progress towards Sustainability. Sustainability 2020, 12, 9716. [CrossRef]

13. Brodny, J.; Tutak, M.; Saki, S.A. Forecasting the Structure of Energy Production from Renewable Energy Sources and Biofuels in Poland. Energies 2020, 13, 2539. [CrossRef]

14. Marks-Bielska, R.; Bielski, S.; Pik, K.; Kurowska, K. The Importance of Renewable Energy Sources in Poland's Energy Mix. Energies 2020, 13, 4624. [CrossRef]

15. Pronobis, M.; Kalisz, S.; Majcher, J.; Wasylów, J.; Sołtys, J. Possibilities of using biomass in district heating with focus on agricultural biomass as a fuel to replace coal, taking into account economic and technical aspects. Instal 2020, 3, 17-25. (In Polish)

16. Laitinen, S.; Laitinen, J.; Fagernäs, L.; Korpijärvi, K.; Korpinen, L.; Ojanen, K.; Aatamila, M.; Jumpponen, M.; Koponen, H.; Jokiniemi, J. Exposure to biological and chemical agents at biomass power plants. Biomass Bioenergy 2016, 93, 78-86. [CrossRef]

17. Dutkiewicz, J. Bacteria and fungi in organic dust as potential health hazard. Ann. Agric. Environ. Med. 1997, 4, 11-16.

18. Mack, S.M.; Madl, A.K.; Pinkerton, K.E. Respiratory Health Effects of Exposure to Ambient Particulate Matter and Bioaerosols. Compr. Physiol. 2019, 10, 1-20.

19. Gołofit-Szymczak, M.; Ławniczek-Wałczyk, A. Biomass as a source of biological hazards [Biomasa jako źródło zagrożeń biologicznych]. Bezpieczeństwo Pracy Nauka I Praktyka 2011, 12, 17-19.

20. Bragoszewska, E. The Dose of Fungal Aerosol Inhaled by Workers in a Waste-Sorting Plant in Poland: A Case Study. Int. J. Environ. Res. Public Health 2019, 17, 177. [CrossRef] [PubMed]

21. Di Filippo, P.; Pomata, D.; Riccardi, C.; Buiarelli, F.; Perrino, C. Fungal contribution to size-segregated aerosol measured through biomarkers. Atmos. Environ. 2013, 64, 132-140. [CrossRef]

22. Latif, M.T.; Yong, S.M.; Saad, A.; Mohamad, N.; Baharudin, N.H.; Bin Mokhtar, M.; Tahir, N.M. Composition of heavy metals in indoor dust and their possible exposure: A case study of preschool children in Malaysia. Air Qual. Atmos. Health 2014, 7, 181-193. [CrossRef]

23. Nasir, Z.A.; Colbeck, I.; Nasar, Z.A. Assessment of Bacterial and Fungal Aerosol in Different Residential Settings. Water Air Soil Pollut. 2010, 211, 367-377. [CrossRef]

24. Byeon, J.H.; Park, C.W.; Yoon, K.Y.; Park, J.H.; Hwang, J. Size distributions of total airborne particles and bioaerosols in a municipal composting facility. Bioresour. Technol. 2008, 99, 5150-5154. [CrossRef] [PubMed]

25. Raisi, L.; Aleksandropoulou, V.; Lazaridis, M.; Katsivela, E. Size distribution of viable, cultivable, airborne microbes and their relationship to particulate matter concentrations and meteorological conditions in a Mediterranean site. Aerobiologia 2012, 29, 233-248. [CrossRef]

26. Li, M.; Qi, J.; Zhang, H.; Huang, S.; Li, L.; Gao, D. Concentration and size distribution of bioaerosols in an outdoor environment in the Qingdao coastal region. Sci. Total Environ. 2011, 409, 3812-3819. [CrossRef]

27. Ławer, K.M. Skażenie mikrobiologiczne powietrza W miejscowościach atrakcyjnych turystycznie. Kosmos 2019, 68, 429-441. [CrossRef]

28. Nevalainen, A.; Willeke, K.; Liebhaber, F.; Pastuszka, J.S.; Burge, H.; Henningson, E. Bioaerosol sampling. In Aerosol Measurement: Principles, Techniques and Applications; Willeke, K., Baron, P., Eds.; Van Nostrand Reinhold: New York, NY, USA, 1993 ; pp. 471-492.

29. Andersen, A.A. New sampler for the collection, sizing, and enumeration of viable airborne particles. J. Bacteriol. 1958, 76, 471-484. [CrossRef]

30. PN-EN 12322 In Vitro Diagnostic Medical Devices. Culture Media for Microbiology. Performance Criteria for Culture Media. 2005. Available online: https://ec.europa.eu/growth/single-market/european-standards/harmonised-standards/iv-diagnosticmedical-devices_en (accessed on 20 February 2021).

31. ISO 11133 Microbiology of Food, Animal Feed and Water-Preparation, Production, Storage and Performance Testing of Culture Media. 2014. Available online: https:/ /www.iso.org/standard/53610.html (accessed on 20 February 2021).

32. Dutkiewicz, J.; Górny, R.L. Biologic factors hazardous to health: Classification and criteria of exposure assessment. Med. Pr. 2002, $53,29-39$.

33. Mentese, S.; Rad, A.Y.; Arısoy, M.; Gullu, G.H. Seasonal and Spatial Variations of Bioaerosols in Indoor Urban Environments, Ankara, Turkey. Indoor Built Environ. 2011, 21, 797-810. [CrossRef]

34. Bragoszewska, E. Exposure to Bacterial and Fungal Aerosols: Microorganism Indices in A Waste-Sorting Plant in Poland. Int. J. Environ. Res. Public Health 2019, 16, 3308. [CrossRef] [PubMed]

35. Lu, R.; Pørneki, A.; Lindgreen, J.; Li, Y.; Madsen, A. Species of Fungi and Pollen in the PM 1 and the Inhalable Fraction of Indoor Air in Homes. Atmosphere 2021, 12, 404. [CrossRef] 
36. Owen, M.; Ensor, D.; Sparks, L. Airborne particle sizes and sources found in indoor air. Atmos. Environ. Part A. Gen. Top. 1992, 26, 2149-2162. [CrossRef]

37. Lacey, J.; Dutkiewicz, J. Bioaerosols and occupational lung disease. J. Aerosol Sci. 1994, 25, 1371-1404. [CrossRef]

38. Bragoszewska, E.; Pastuszka, J.S. Influence of meteorological factors on the level and characteristics of culturable bacteria in the air in Gliwice, Upper Silesia (Poland). Aerobiologia 2018, 34, 241-255. [CrossRef] [PubMed] 